\title{
DEP Domain-Containing mTOR-Interacting Protein
}

National Cancer Institute

\section{Source}

National Cancer Institute. DEP Domain-Containing mTOR-Interacting Protein. NCI

Thesaurus. Code C101595.

DEP domain-containing mT OR-interacting protein (409 aa, $\sim 46 \mathrm{kDa}$ ) is encoded by the human DEPT OR gene. This protein plays a role in the regulation of mT OR signaling. 